\title{
JUSTIÇA E MISERICÓRDIA NA MESA DO SANTO OFÍCIO DE LISBOA: as penas dos padres sodomitas
}

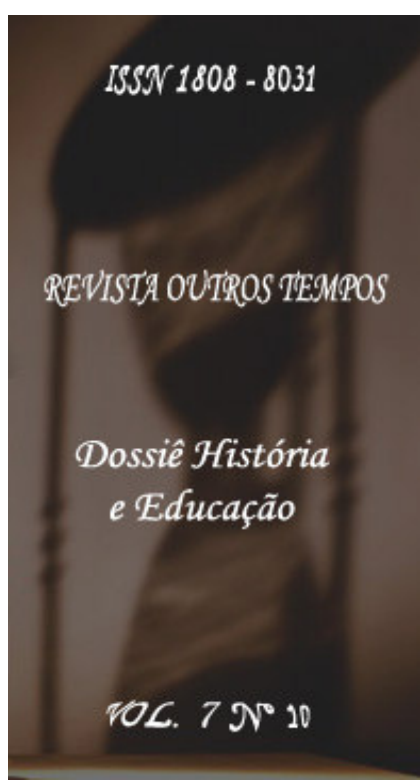

\author{
Ms. Verônica de Jesus Gomes \\ veronicagomes_07@yahoo.com.br
}

Resumo: Não obstante as preocupações dos concílios, especialmente as do de Trento, quanto à disciplina eclesiástica, a alcunha medieval vício dos clérigos caracterizou bem o contexto de Portugal e do Brasil dos séculos XVI- XVIII, quando vários homens da Igreja se envolveram com o pecado da sodomia. O artigo analisa as punições que lhes foram dadas pelo Santo Ofício português, uma importante instituição do Antigo Regime, procurando comprovar não só possíveis privilégios, como também a misericórdia inquisitorial perante os confitentes e os denunciados. Além disso, analisa a colaboração da justiça da Igreja para com a engrenagem do Tribunal, uma vez que colheu denúncias, auxiliou nas prisões e no envio de pecadores a Lisboa.

Palavras-chave: Portugal. Inquisição. Sodomia. Padres

Abstract: Nevertheless the councils' preoccupations, especially from Trent, with ecclesiastic discipline, the expression clerical vice characterized Portugal and Brazil contexts in XVI - XVIII centuries, when many men of the Church practiced sodomy. This article analyzes the punishments given to the sodomite ecclesiastics by the Portuguese Inquisition, an important Ancient Regime institution, trying to observe the privileges and the inquisitorial clemency to the ecclesiastics who confessed their sins and to the others who were accused. Besides, it analyzes the justice from the Church that helped the Inquisition, hearing people who accused the priests, helping to capture the sodomites from the Church and sending them to Lisbon.

Key-words: Portugal, Inquisition. Sodomy. Priests

\footnotetext{
${ }^{1}$ Artigo recebido em 15/8/2010 e aceito em 6/10/2010.
} 
Crime e castigo na prática da sodomia em Portugal: a igreja, o estado e a inquisição

Durante séculos, a sodomia foi caracterizada pelos teólogos medievais de forma ampla, podendo referir-se tanto aos relacionamentos entre pessoas do mesmo sexo, quanto aludir a vários tipos de práticas sensuais excessivas, que iam desde a masturbação até o incesto, do adultério à bestialidade. No que se refere aos atos, foi dirigida especialmente aos anais e orais, dentre outros contatos genitais contra a natureza, especificados nos penitenciais da Alta Idade Média.

Vainfas, fundamentando-se nos estudos de Boswell, declarou que, a partir dos séculos XII e XIII, os atos sodomíticos adquiriram um contorno mais específico dentro da morfologia cristã da luxúria, quando foram estritamente ligados ao sexo anal praticado entre homens (VAINFAS, 1986-1987). A tolerância quanto aos desviantes sexuais, que se manteve até o início do século XII, foi, a partir de então, substituída pela hostilidade, que marcou principalmente o XIII e o XIV. Nesse período, as penalidades recrudesceram, passando a se prescreverem a castração, a mutilação e a fogueira, variando de acordo com o disposto nos diferentes códigos europeus (BOSWELL, 1998, p. 289-290). Seja como for, é importante destacar que Santo Agostinho já assinalava, em suas Confissões (III, 8), que os praticantes do pecado de Sodoma deveriam ser sempre punidos:

[...] pecados contra a natureza, por conseguinte, assim como o pecado de Sodoma, são abomináveis e merecem punição sempre que forem cometidos, em qualquer lugar que sejam cometidos. Se todas as nações os cometessem, todas igualmente seriam culpadas da mesma acusação na lei de Deus, pois nosso Criador não prescreveu que pudéssemos utilizar uns aos outros dessa maneira. Na realidade, a relação que devemos ter com Deus é ela mesma violada quando nossa natureza, da qual ele é o Autor, é profanada pela lascívia perversa (RICHARDS, 1993, p. 136) (grifo meu).

Na Península Ibérica, já no século XIII, o Código de Afonso, o Sábio, ordenava que tanto o agente quanto o paciente deveriam morrer, "exceto si alguno dellos lo hobiese á facer por fuerza ó fuese menor de catorce años; ca estonce non deben recibir pena, porque los que son forzados non son en culpa; otrosi los menores non entienden que sea tan grant yerro como es el que facen" (BOSWELL, 1998, p. 310).

Considerada pela Igreja como uma das principais manifestações da luxúria, a sodomia foi motivo de inquietação, vista como uma transgressão capaz de atrair perigosos castigos 
divinos. Em Portugal, algumas constituições dos arcebispados e dos bispados que zelavam "pela pureza da religião e pelos bons costumes" a condenaram, já que, por sua prática, Sodoma e Gomorra foram destruídas por Deus. Perpetrada no âmbito privado, passava a ter consequências coletivas, constituindo-se como o pecado que mais aborrecia a Deus, ofendendo não só o Criador, mas toda a natureza criada, celestial e humana. Daí a Constituição do Arcebispado de Braga, de 1697, determinar que,

[...] quando algum Clerigo ou pessoa de nossa jurisdição for tam infeliz e carecido do lume da razão natural, e esquecido de sua salvação, (o que nosso Senhor não permita), que seja convencido haver co'metido tam feyo delito, e peccado, sera privado do Officio, e Beneficio, e qualquer Dignidade Ecclesiastica, que tiver; e degredado realmente [...] das Ordens, e entregue também à Justiça secular (AGUIAR, 1930, p. 12-13).

Transgressão das mais graves, também preocupou as autoridades civis e foi alvo de condenação dos códigos legislativos das monarquias cristãs ibéricas. Em Portugal, também designada pecado nefando - "cousa indigna de se exprimir com palavras: cousa da qual não se pode fallar sem vergonha" - constituiu-se um dos principais desvios morais a ser perseguido. O Padre Bluteau definiu-a como prática que nem mesmo o diabo era capaz de cometer: "chama-se o demonio Incubo, ou Succubo, de servir hora de home', hora de mulher, no acto carnal, mas em nenhum Author se lè, que tenha commettido o peccado nefando, prova evidente de que he torpeza tão enorme, que atè o demonio a aborrece" (BLUTEAU, 1712-1728, p. 99; 772) (grifo meu).

As Ordenações do Reino português foram rigorosas no julgamento do pecado/crime, ao preverem penas bastante severas aos réus, incluindo a morte, como já prescreviam, no século XV, as Ordenações Afonsinas (1476/1477). A pena capital foi confirmada posteriormente, quando tanto as Manuelinas (1514/1521) quanto as Filipinas (1603) ordenaram que fossem queimados, reduzidos a pó, para que suas memórias fossem destruídas.

Contudo, as três Ordenações não foram os únicos códigos legislativos portugueses que censuraram e penalizaram os pecadores, uma vez que as Leis Extravagantes também tiveram o mesmo objetivo. A de D. Sebastião, de 9 de março de 1571, publicada pela Chancelariamor, em Lisboa, em 26 de junho de 1571, por exemplo, se debruçava "sobre a prova e o procedimento contra os culpados no pecado de sodomia” (AGUIAR, 1930, p. 4).

Em Portugal, a transgressão, que se encontrava sob a jurisdição eclesiástica e a civil, passou ao controle inquisitorial em $1^{\circ}$ de setembro de 1552, após comissão do Arcebispo de

\footnotetext{
2 Íncubo era o demônio que assumia a forma de um homem para cometer torpezas com mulheres; por sua vez, o súcubo era o demônio que, "para excitar os homens a luxuria e cohabitar com elles, toma figura de mulher". Verbetes consultados no dicionário de Bluteau: nefando, íncubo e súcubo.
} 
Lisboa, D. Fernando de Meneses Coutinho e Vasconcelos. A partir de então, os inquisidores poderiam tomar "por escrivão para isso qualquer notário da Santa Inquisição ou do nosso Auditório de que eles confiarem, descarregando nossa consciência e encarregando a sua". A cooperação poderia proceder "contra todalas pessoas de que até ao presente lhe é denunciado culpadas no dito crime, ou for denunciado ao diante" (PEREIRA, 1987, p. 35).

Mas, já em 1550, D. João III solicitava ao Sumo Pontífice a jurisdição inquisitorial sobre o pecado nefando, no que foi atendido pelo Breve Exponi nobis nuper, concedido pelo Papa Pio IV, em 20 de fevereiro de 1562. Em 1553, um Alvará de D. João III concedeu inteira jurisdição aos inquisidores para que indagassem sobre os praticantes do delito. Foi confirmado em 30 de maio de 1560, documento que não apenas ressaltou a jurisdição inquisitorial sobre quaisquer pessoas de qualquer qualidade e condição, como estendeu a autorização da atuação dos Juízes do Tribunal contra os réus que vestissem hábito das Ordens Militares de Cristo, Santiago e Avis (p. 48-49).

Em 24 de maio de 1555, o Cardeal Infante D. Henrique passou uma Comissão aos inquisidores de Lisboa, para que conhecessem o crime nefando e contra natura. Utilizando-se da auctoritate apostolica, concedia a cada um dos inquisidores lisboetas o "comprido e inteiro poder para que possam conhecer contra quaisquer pessoas privilegiadas de qualquer grau, ordem, estado e qualidade que sejam, isentos e não isentos, de que lhes for denunciado serem culpados do crime nefando de sodomia e contra natura" (p. 29) (grifo meu).

Dessa forma, após uma série de bulas papais e documentos régios, a Inquisição, finalmente, exerceu seu controle sobre o pecado abominável. O primeiro Regimento inquisitorial a tratar da herança maldita de Sodoma foi o de 1613. De autoria do Bispo D. Pedro de Castilho, Inquisidor Apostólico Geral que, segundo os próprios transgressores, "não perdoava os sodomitas" (MOTT, 1988), o conjunto normativo de 1613 foi elaborado durante a União Ibérica, período em que Portugal estava sob a Coroa de Castela. É importante sublinhar que a Inquisição espanhola perseguiu tais culpados de maneira muito mais relevante do que a portuguesa, pelo menos no que se refere à pena capital. A aparente benevolência lusitana para com esses pecadores deveu-se à melhor estrutura de sua congênere espanhola, além do intenso antijudaísmo português (VAINFAS, 1997, p. 304).

Sob direta influência da evocada provisão passada pelo Cardeal D. Henrique, em 1555, as disposições regimentais de 1613 reafirmaram o poder inquisitorial sobre faltosos de qualquer qualidade, estando inseridos os clérigos. A sodomia tinha seu procedimento judicial semelhante ao realizado nos crimes de heresia e apostasia, cujos culpados deveriam ser condenados às penas que parecessem devidas aos inquisidores e às que, pela Ordenação 
Régia, estavam estabelecidas contra os semelhantes, até serem relaxados à justiça secular. $\mathrm{O}$ pecado nefando foi o único crime moral passível de fogueira, segundo a Inquisição lusitana.

Apesar das importantes disposições quanto à organização processual e às punições dos sodomitas em 1613, o Regimento de 1640 foi, indubitavelmente, muito mais sistematizado. De autoria do Bispo e Inquisidor-Geral D. Francisco de Castro, esse regimento, bem mais completo, dedicou maior espaço à sodomia, especificando os castigos, as circunstâncias e quando deveriam ser aplicados.

Dessa forma, tanto os que procurassem a Mesa Inquisitorial pela primeira vez - não estando delatados - quanto os que se apresentassem depois de denunciados seriam recebidos com misericórdia. Todavia, não se tratava de uma medida benevolente. Procurava-se evitar que a pena pública e a infâmia impedissem "os culpados de vir confessar suas culpas e descobrir os cúmplices com que as cometeram" (ASSUNÇÃO e FRANCO, 2004, p. 375).

As penalidades recrudesciam nos casos dos que fossem considerados diminutos, devassos e escandalosos, e incluíam degredo, açoites [estes para os que não fossem de qualidade], confisco de bens, além da condenação máxima - a fogueira - destinada aos que, apresentados pela terceira vez, tivessem contra si prova legítima do lapso triplicado, já que eram tidos por incorrigíveis, e aos chamados presos convictos.

Todo culpado e detido pelo crime, antes de se confessar à Inquisição, a leigos e a eclesiásticos (seculares ou regulares), estando convencido pela prova da justiça ou confessando sua falta, depois de preso, "sendo exercente, (o que se entenderá se ao menos confessar ou contra ela se provarem dois actos consumados), será relaxada à justiça secular e seus bens confiscados, salvo se for menor de vinte anos ou concorrerem tais circunstâncias no caso e na qualidade da pessoa" (p. 376).

Nesse caso, se não the fosse dada a pena comum, receberia a extraordinária, a mais grave possível. Entretanto, Mott salientou que poucas foram as vezes em que os inquisidores se utilizaram de toda a severidade prevista. Os trinta réus queimados nos três tribunais portugueses, Lisboa, Coimbra e Évora - três no século XVI e vinte e sete no XVII - foram tidos como incorrigíveis, devassos e escandalosos, tendo persistido na prática execrável durante muitos anos, sem perspectiva de emenda. O século XVIII marcou o declínio persecutório, quando o tribunal conimbricense realizou a última prisão, em 1711, e em 1768 foram presos os últimos transgressores pelas Inquisições de Lisboa e de Évora (MOTT, 1988).

O regimento de 1640 previa ainda que qualquer réu que fosse convencido do crime, por sua confissão ou através da prova da justiça, e que não fosse entregue a julgamento 
secular, ouviria sua sentença no Auto de Fé, sendo condenado não apenas ao confisco de bens, mas também ao açoite e ao degredo para as galés pelo tempo que conviesse. É interessante observar as medidas prescritas aos homens da Igreja:

[...] sendo clérigo, terá as mesmas penas, excepto a de açoites, e será suspenso para sempre das ordens que tiver e inabilitado para ser promovido às que lhe faltarem e, tendo ofício ou benefício eclesiástico, será privado dele e inabilitado para ter outros. E se for religioso professo, ouvirá sua sentença na sala do Santo Ofício e será também suspenso das ordens, privado de voz activa e passiva para sempre e degredado para um dos mosteiros mais apartados de sua religião, onde terá algum tempo de reclusão no cárcere, com as penitências que se costumam dar aos religiosos por culpas gravíssimas. E poderá também ser degredado para algum lugar fora do reino, tendo-se respeito à graveza do crime e qualidade da pessoa, mas em caso que sejam devassos no crime e escandalosos, irão ouvir sua sentença no auto e serão também condenados em degredo para galés (ASSUNÇÃ̃O e FRANCO, 2004, p. 376) (grifos meus).

O último regimento inquisitorial, de 1774, de autoria do Cardeal da Cunha, confirmou as penalidades mais enérgicas aos incorrigíveis e infandos pecadores. Muito embora as chamadas testemunhas singulares tenham sido abolidas nesse regimento, continuavam a ser indispensáveis no caso dos atos sodomíticos, uma vez que "ficariam impunidos, sendo tão abomináveis, se neles se não admitisse prova de toda a qualidade”. Entretanto, as testemunhas inábeis e defeituosas ficaram excluídas no caso das penas de morte, infâmia e confisco de bens, sendo utilizadas somente para as extraordinárias, "para por elas se purgarem os indícios que fazem contra os réus" (p. 447).

Vale a pena destacar o que previa o projeto de um novo regimento, de autoria de Pascoal José de Melo, que não chegou a entrar em vigor. Assinalava que a Inquisição "não conhecia deste crime pela sua instituição, mas por leis posteriores que o autorizaram". O Santo Ofício só deveria preocupar-se com os sodomitas públicos e escandalosos. A pena capital seria abolida e eles, condenados às galés (de cinco até dez anos), "com hábito particular que os distinga dos outros" (p. 515). Caso houvesse juízo secular conhecido no crime, o Santo Ofício não deveria intrometer-se no caso.

Marcado por "um entendimento da realeza onde o religioso e o político surgem lado a lado, chegando mesmo a interpenetrar-se," o Estado português, ao buscar a ortodoxia, religiosa e a moral de seus súditos, criou a Inquisição. Uma instituição de caráter híbrido, que, mesmo se constituindo como "tribunal eclesiástico, não deixou de se afirmar como tribunal régio" (CARDIM, 2001, p. 146; BETHENCOURT, 1993, p. 153). Afinal, a Igreja, antes mesmo da instalação do Tribunal Inquisitorial, possuía meios disciplinadores muito eficazes, exercendo grande influência na vida cotidiana da comunidade, contando com especial apoio régio para a concretização de um controle social (CARDIM, 2001, p. 135). Desse modo, foi 
uma instituição que, juntamente com o Estado e a Inquisição, formou uma tripla frente contra os praticantes de atos sexuais ilícitos.

\section{Os padres sodomitas no banco dos réus}

A expressão medieval vício dos clérigos, popularizada a partir da obra de São Pedro Damião, Liber Gomorrhianus, ou O Livro de Gomorra, escrito entre 1048 e 1054, cabe perfeitamente no contexto de Portugal e do Brasil dos séculos XVI-XVIII. O período marcou o envolvimento de vários homens da Igreja com o pecado de Sodoma, não obstante os esforços dos concílios, especialmente os de Trento, para moralizar o clero.

Conforme já destacado, trinta sodomitas foram relaxados à justiça secular, nenhum do Brasil. Desses réus queimados, é imprescindível destacar que pelo menos sete eram homens da Igreja $^{3}$ (MOTT, 1992, p. 728). Por meio das denúncias e das confissões contidas nos Cadernos do Promotor e do Nefando, das que estão nos livros das Visitações Inquisitoriais à Bahia (1591 e 1618) e de processos da Inquisição de Lisboa, foi localizado um expressivo número de membros da Igreja descobertos pelo Santo Ofício português por causa da prática do pecado infame de atos sexuais entre homens.

Pelo menos um processo foi elaborado durante a primeira Visitação Inquisitorial às terras brasílicas no século XVI: o de Padre Frutuoso Álvares, vigário de Matoim, Bahia, o primeiro a buscar a mesa do Santo Ofício para "descarregar sua consciência". No século XVII, quando pelo menos trinta e sete homens da Igreja foram denunciados ou procuraram a Inquisição para confessar suas culpas, o que parece confirmar ter sido um período emblemático, marcado por uma atuação inquisitorial mais ativa sobre os infratores, pelo menos oito processos de réus eclesiásticos foram mapeados. Por sua vez, no século XVIII, localizei, até o momento, apenas o processo de Padre José Ribeiro Dias.

A colaboração da justiça eclesiástica para com o Santo Ofício foi de suma importância no que tange ao sucesso da diligência inquisitorial contra vários transgressores, dentre eles os pecadores infandos. Bruno Feitler (2007, p. 17) assinalou a participação do clero secular e do regular na atuação da Inquisição no Brasil. Ambos, juntamente com um expressivo número de agentes inquisitoriais, contribuíram, de maneira contundente, para a sua efetiva atividade, uma vez que o processo ia da coleta das denúncias à captura dos réus, passando por uma incisiva interação com o poder episcopal.

\footnotetext{
${ }^{3}$ Entretanto, Mott afirma, em outro texto, Pagode Português, que nove clérigos foram relaxados à justiça secular, isto é, " $1 / 3$ dos sodomitas queimados em Portugal pertenciam à Igreja". Assim, esses são números que ainda procurarei confirmar.
} 
Daniela Calainho (2006, p. 76), baseada em Jaime Contreras, afirma que, durante os séculos XVII e XVIII, a vasta rede de familiares e comissários que se instalou em terras brasílicas, "desempenhou um papel importantíssimo na estratégia do Santo Ofício para exercer o controle social da população colonial e reorientar as condutas supostamente desviantes".

É nesse sentido que a cooperação da justiça eclesiástica e a atuação dos comissários inquisitoriais tiveram papel fundamental na captura de um clérigo no século XVIII, o Padre José Ribeiro Dias, cujo processo teve início a partir de um sumário de culpas enviado pelo bispo do Rio de Janeiro à Mesa do Santo Ofício lisboeta. Denunciado por um de seus escravos, o mulato Phelippe de Santiago, teve sua prisão decretada pelo Conselho Geral que, após o exame do sumário do bispo, determinou ao comissário que o remetesse preso, com sequestro de bens, para Lisboa (ANTT, IL, Proc. n. 10426).

Foi um dos execráveis réus da Igreja que recebeu a pena inquisitorial mais severa. Filho do mercador Manoel Ribeiro Dias, foi entregue ao alcaide e meirinho em 24 de janeiro de 1747, sob acusação de inúmeras cópulas com diversos homens. Sua sentença juntamente com as de Padre Vicente Nogueira (século XVII) e de Padre Frutuoso Álvares serão aqui analisadas.

Após consulta ao Conselho Geral, foi determinada sua sentença, que, como era praxe, contou com a participação dos inquisidores, do ordinário e dos deputados da Santa Inquisição. A decisão, no final de seu processo, concluído em 21 de julho de 1747, proclamou o réu convicto e confesso do pecado de que era acusado, incorrendo em pena de infâmia e confísco de todos os seus bens. Padre Ribeiro Dias foi condenado ao Auto de Fé Público - que contou com as presenças do Rei D. João V, dos Infantes D. Pedro e D. Antonio, além de inquisidores "e mais Ministros da Meza muita Nobreza e povo" - à suspensão permanente de suas ordens, à privação de quaisquer ofícios e benefícios e à inabilitação para outros, além de receber a sentença de degredo para as galés de El-Rei por dez anos. Ainda que fosse muito difícil livrarse dos grilhões das galés - bom comportamento, mostras de resignação, idade avançada e, até mesmo, a debilidade física do réu não eram elementos suficientes para aguçar a misericórdia dos inquisidores (SANTOS, 2005, p. 292; 294) - o padre secular, após sete anos cumprindo tal pena, conseguiu comutá-la.

Escreveu ao Santo Ofício, pedindo misericórdia e piedade "pella Payxão de N. Sn. Jezu Christo, e dores de Sua Santissima May”, descrevendo os dolorosos momentos vividos nas galés, tendo chamado a atenção para os perigos da salvação de sua alma: 
[...] nahorroroza prizão emq está, q mais pareçe sepultura qhabitassão, passando as horas do diae noite atonito com o espectaculo dos seus infortunios, qroubandolhe até dos olhos o sono, lhe negão aquelle descanso, de q a naturezahe[?] [...?] liberal Com Os mortaes, padecendo nella hua' febreMaligna, ficou com enfermidades, Com ja [?] reprezentou emostrou por Certidão, sendo amayor[?] enfermid.[e] aVellicie[?]; Com olemitado, egroçeiro sustento q' selhedá, a RoupaComq foi $\mathrm{p}^{\mathrm{a}}$ agallé Rota , Sem ter já q.[m] osocorra Como hé vulgar com os prezos Em prizoins de m.t. ${ }^{\circ}$ sannos; Com tantas aflisoins proximo acahir [?] em impaciência Comevidente RiscodaSalvação daSuaalma, havendo as sofrido Com mt. ${ }^{\mathrm{a}}$ paciençia e, eVerdadeiramt.[e] arrependido de Suas Culpas, humilde e [...?]ivamt.[e] rogando a V.V. Ill. as e implorando asua mesma benignidade (ANTT, IL, Proc. 10426).

Reduzido à completa miséria, ficando à mercê de esmolas para se sustentar e se vestir, Padre Ribeiro Dias ainda tentou obter a misericórdia inquisitorial e pediu para que voltasse a exercitar o ofício eclesiástico:

[...] epoderhonestamt.[e] Viver, se lhe entreguem as suas cartas de ordens, e mais papeis qslhe tomarão a donde foi prezo, eSehavião de Remeter aoSt. ${ }^{\circ}$ Tribunal, Epor tão grd.[e] Esmola será perpetuo oradoraD.[s] pela vida e Saude de V.V. Illm. ${ }^{a}$ s'. Contudo, não teve seu pedido deferido e a decisão da Mesa, de 5 de novembro de 1754, afirmou que: 'Pareçemos que não está em termos de selhedeferir' (ANTT, IL, Proc. n. 10426) (grifo meu).

Por sua vez, o Cônego da Sé de Lisboa, Padre Vicente Nogueira, ativo e passivo com seus inúmeros amantes, foi preso em 17 de junho de 1631. Fidalgo de importante casa portuguesa, poliglota, licenciado em Cânones por Coimbra, teve os autos, as culpas e as confissões vistas pela Mesa Inquisitorial em 22 de novembro de 1632. Pareceu a todos os votantes que o réu, em face da gravidade do delito e de sua qualidade, além da prova que tinham, deveria ouvir sua sentença na sala do Santo Ofício, na presença de inquisidores, deputados e oficiais, além de alguns capitulares da Sé, religiosos e sacerdotes.

A decisão do Conselho Geral saiu em 4 de dezembro de 1632. A sentença o declarou convicto e confesso no crime de que era réu, incorrendo em privação de seus benefícios e confisco de todos os bens:

[...] uzando com ellede muita misericordia, Mandão que oReo ouça Suasentença nasalla do Santo Officio, ante os Inquisidores eseus officiaes eoutras pessoas defora quelhes pareçer, e osuspendem do exerçiçio desuasOrdens e uzo dellas te merçe do Illustrissimo Senhor Inquisidor Geral eodegradão peraSempre pera a Ilha do Principe e cumprira as mais penas epenitençias espirituais quelheforem impostas (ANTT, IL, Proc. n. 4241).

Padre Nogueira ouviu sua sentença no Auto de Fé Privado no dia 8 de janeiro de 1633, em que estiveram presentes os senhores inquisidores, os deputados, os Ministros do Santo Ofício e muitas pessoas graves, eclesiásticas e seculares.

Mesmo ficando provado que praticou sodomia inúmeras vezes e em diversas ocasiões, o que lhe valeu ser declarado convicto e confesso do crime, o padre não se deu por vencido. 
Quando soube de seu degredo perpétuo na Ilha do Príncipe, fez de próprio punho uma petição em que enumerava pelo menos seis motivos para que não fosse para lá e que a pena fosse cumprida em Angola.

Discorrendo, no primeiro ponto, sobre os perigos da viagem, pedia pelas chagas de Cristo que os membros do Santo Tribunal não o embarcassem para a ilha. Ao que parece, ainda que os inquisidores Diogo Osório de Castro e Pedro da Silva de Sampaio se tenham referido a Nogueira como "sacerdote, pessoa nobre; ede bom entendim[t]", não deferiram seu pedido. Foi embarcado para a Ilha do Príncipe em 29 de agosto de 1633, sob os cuidados de Agostinho Freire, mestre do navio Nossa Senhora dos Remédios.

Contudo, entre $1^{\circ}$ e 9 de fevereiro de 1635, Nogueira e seu criado Nunes foram denunciados ao Santo Ofício por três testemunhas. Fora visto na Paraíba, vestindo roupas de clérigo, usando barba e bigode e chamando-se Domingos Pereira. Desafiando os membros do Tribunal, o inveterado padre embarcou numa caravela com destino ao Reino e, durante a travessia, continuou com seu comportamento irreverente, acometendo os rapazes para a prática do pecado nefando, como afirmou, em sua denúncia, Vicente de Britto, criado do Capitão Lourenço de Brito Correa: "od. ${ }^{\circ}$ Vicente Nogueira do mesmo camarotte, que tinha huas' taboas largas lançava fora amao' ecom ella tocava nos trazeiros detres rapazes, que vestidos hiao' junto aoleme p. se revezare' ao governo delle, e os moços se envergonhavão, efazião vermelhos" (ANTT, IL, Proc. n. 4241).

Segundo outra testemunha, Padre Bento Pais, o sacerdote Nogueira esteve por um tempo no engenho de Jorge Lopes Brandão, que tinha fama pública "por seus mãos costumes". Padre Bento acrescentou ainda que, segundo alguns rapazes, na viagem ao Reino, o clérigo lhes dava tostões e lhes prometia vestimentas e dinheiro assim que desembarcassem. Tal comportamento foi confirmado pelo Capitão Brito Correa, que acrescentou haver forte suspeita de que o padre tivesse cometido sodomia dentro do navio. Além de ter tentado impedir que embarcasse na caravela, o capitão ainda disse que, na Paraíba, era cousa muito notória e sabida que fora preso e condenado pela Inquisição por esse cometimento.

Seu processo termina com as três denúncias. Mas, segundo Mott (1999, p. 51), ele fugiu para a Itália, onde contou com a proteção do Cardeal Francisco Barberino.

Padre Frutuoso Álvares, o primeiro a procurar a Mesa Inquisitorial durante a Visitação à Bahia, em 1591, para confessar seu envolvimento sodomítico com vários rapazes, foi beneficiado por ter declarado suas culpas na Graça. Natural de Braga, filho de João Álvares, 
pichaleiro $^{4}$, cometera tocamentos torpes com dois mancebos e apresentou uma demissória ${ }^{5}$ falsa em Cabo Verde. Pelos crimes, foi enviado, preso, a Lisboa. Recebeu como pena o degredo perpétuo no Brasil.

Não se emendou e, na Bahia, foi acusado pelos "mesmos peccados e tocamentos torpes”. Apesar de seu complexo contexto, já que teve cerca de quarenta parceiros, com quem praticou os chamados tocamentos desonestos (vale lembrar que esse conjunto de pecados não estava sob jurisdição inquisitorial) em Portugal e Cabo Verde, além de na Bahia, confessou que cometeu e consumou o pecado de sodomia com apenas dois jovens: Jerônimo Parada, no Brasil, e Francisco Dias, em Braga. Além disso, confessou-se no período da graça e, ainda que tenha sido denunciado pelo ato nefando com Jerônimo, não amargou uma penalidade tão severa.

Embora sua confissão tenha sido considerada diminuta - esqueceu, no tempo da graça, de declarar a culpa principal e substancial, isto é, o ato consumado com Jerônimo Parada, lembrando-se de torpezas menos graves e mais antigas - recebeu a misericórdia inquisitorial. Segundo a sentença, devido à sua pronta resposta logo na primeira sessão, quando confirmou a culpa nefanda por que fora delatado, confessando suas torpezas sem ser chamado, usar-se-ia com ele de muita misericórdia:

[...] mas que the esqueçeo deho confessar naditta co'fissão do te'po da graça parece lhe que lhe não devya esquecer pois era acto deculpa consumadatamgrave elhelembrarão as outras torpezas menos graves emais antiguas. Pello que pois nadittasua comfissão foy demenuto enão confessou Inteyramente todas as culpas de que foy delato mas deyxouamais grave epryncypalperdeo, o benefficyo da graça que alcançarasefizera confissão Inteyra. O quetodo vysto e o mais que destes autos co'sta eo Reo ser tam inteyro, e costumeyro a cometer os dittos peccados sendo tantas vezes Jaaccusado e condenado por elles em Portugual, enocaboverde, eneste brasil, eser de ydadedesesenta eoyto annos, e sacerdote ecura de almas, em ostraz tampouco cuydado de sua salvação que ha tampoucos annos que fez o ditto peccado de sodomya destabahia (?) porem respeytando a o Reo na prymeyra sessão sendopergu'tado confessar a ditta culpa nefanda de que foy dellato, e a (?) ter vyndo na graça comfessar as outras torpezas sen serchamado e aoutras mais con sideraçois' Pias que se tiverão querendo usar co' elle de muyta mia' (ANTT, IL, Proc. 5846).

Desse modo, teve as ordens suspensas por cinco meses, pagou as despesas do Santo Ofício, no valor de vinte cruzados, e foi condenado às seguintes penitências espirituais: fazer confissão geral de toda a sua vida a um padre letrado e douto, nomeado pela mesa, comungar, a partir de então, em cada um dos meses de suspensão, além de rezar cinco vezes os salmos

\footnotetext{
${ }^{4}$ Segundo Bluteau, era o oficial que fazia pichéis (vaso de estanho, ou de outro metal, de boca redonda, para colocar vinho) e outras obras de estanho. Verbetes: pichêl e picheleiro.

${ }^{5}$ De acordo com Salvador e Embil, Dimissória ou Carta para a Ordenação Sagrada (Litterae dimissoriae) "é o documento que o Ordinário próprio (Bispo ou Superior maior) do ordenado envia a um Bispo para que o ordene”. Cf. EMBIL, José María Urteaga; SALVADOR, Carlos Corral (dir.). Dicionário de Direito Canônico. São Paulo: Loyola, 1993, p. 251.
} 
penitenciais. Foi admoestado para que não voltasse a cair nas mesmas torpezas e que se emendasse. Caso contrário, seria punido com todo o rigor da justiça.

Alguns fatores eram básicos para que o réu não recebesse uma pena muito severa: a idade (menores de 25 anos), o número de cópulas - a esperança de emenda era fundamental para que os inquisidores fossem misericordiosos - a confissão antes de ser denunciado, mesmo fora do período da Graça, além de um recurso bastante importante: deveria dar mostras de arrependimento, isto é, comprovar a contrição, definida por Monsenhor Gousset "como uma dor interior e um ódio ao pecado cometido, com o propósito de não mais pecar no futuro" (BECHTEL, 1998, p. 278).

É importante observar que os três padres, Frutuoso Álvares, José Ribeiro Dias e Vicente Nogueira, tiveram inúmeros parceiros, ainda que Frutuoso tenha confessado somente duas práticas sodomíticas consumadas. Seja como for, cometeu vários atos homoeróticos que incluíam os chamados tocamentos desonestos, molícies, abraços, beijos e conatus, ou seja, tentativas de cópula anal sem êxito, com diversos mancebos, o que, embora não interessasse à justiça inquisitorial, era, às vezes, por ela considerado um importante sinal da prática do nefando: "a certeza da multiplicidade dos actos de Molicie, e com tantos complices faz indicio certo para os da Sodomia" (ANTT, IL, Proc. n. 10426).

Contudo, são nítidos os indícios de misericórdia recebida por quem procurava e colaborava com a Inquisição. Padre Frutuoso não estava denunciado, confessou na Graça e, ainda que não tenha recebido seus benefícios (sua confissão não foi inteira, já que se esqueceu de mencionar o ato sodomítico), obteve uma pena branda.

No entanto, Padre José Ribeiro Dias, homem rico, dono de vinte e sete escravos e de lavras na região das Minas - uma delas chegava a custar mais de duzentas oitavas de ouro não conseguiu livrar-se dos severos castigos da Inquisição. Denunciado por seu escravo, que, por respeito à sua condição, permitia ser sodomizado, não teve direito à misericórdia. Enfrentou um Auto de Fé Público, incorreu em pena de infâmia, teve suas ordens suspensas perpetuamente, foi reduzido à miséria e ainda condenado às galés, uma das penas mais rigorosas, que levou um Inquisidor a dizer que "os culpados no crime de sodomia são mais castigados que os hereges porque estes têm penitências de cárcere e hábito por 4 ou 5 anos, e os de sodomia muitos anos de galés" (MOTT, 1992, p. 710).

Em contrapartida, Padre Nogueira, homem nobre, filho do Conselheiro de Estado de El-Rei, ex-desembargador da Casa da Suplicação e que possuía boas relações, conseguiu escapar das penalidades mais severas, ainda que tenha cometido atos sexuais com inúmeros rapazes e em diversas ocasiões e que os inquisidores tenham considerado pequena sua chance 
de emenda. Não foi destituído dos privilégios clericais (só foi condenado à suspensão das ordens até decisão do Inquisidor Geral), não enfrentou a humilhação de um Auto de Fé Público, parecia ter livre trânsito, já que chegou a embarcar para o Reino numa caravela, e ainda não sabemos como não cumpriu o degredo na Ilha do Príncipe.

Embora tenha cometido o pecado com "grande atrevimento", perseverando nele por anos e se utilizando de várias estratégias para conseguir satisfazer seus desejos, não recebeu a marca da infâmia. Ciente de que as penas ordinárias destinadas aos sodomitas eram "a vida, honra e fazenda" e sempre preocupado com sua dignidade, escreveu ao Inquisidor Pedro da Silva de Sampaio, homem de "fidalga e boa natureza", implorando para "conservar a honra e opinião, e não envergonharme" (ANTT, IL, Proc. 4241).

Calcada numa noção corporativa, concebida como um corpo articulado e naturalmente hierarquizado por vontade divina, a sociedade portuguesa do Antigo Regime era marcada por contrastes e privilégios. De acordo com Calainho (2006, p. 65), baseada nas proposições de Max Weber, pode ser caracterizada como predominantemente de tipo estamental, uma vez que se moldava em valores tais como a honra e o privilégio de um ou mais grupos, não sendo, necessariamente, vinculada a uma situação de classe, em que o fator principal para o status social é o poder econômico. Daí que Vainfas e Neves assinalaram, primeiramente, o privilégio do nascimento, que distinguia a nobreza pelo sangue; em seguida, o privilégio de ofício, que desprezava:

[...] os serviços manuais e valorizava aquele que vivia de rendas; por último, uma série de privilégios particulares, concedidos ad hoc a indivíduos, corporações, casas comerciais, instituições, grupos sociais, que iam desde a autorização para portar espada, ou utilizar um tipo de tecido, até isenções fiscais e direitos exclusivos para produzir ou comerciar certos bens (VAINFAS, 2000, p. 44).

Desse modo, no Portugal do Antigo Regime, a condição social era diferenciada "pelas formas de tratamento e pelo vestuário, implicando estatuto diferente perante a justiça" (CALAINHO, 2006, p. 66). O Regimento de 1640, ao estabelecer o modo de se lidar com os presos, determinava que, embora todos devessem ser tratados por "vós", "no modo de os tratar terão respeito à qualidade de suas pessoas". Portanto, havia os culpados privilegiados, que mereciam cadeiras de espaldas, caso dos clérigos, dos religiosos e das pessoas seculares de qualidade (ASSUNÇÃO e FRANCO, 2004, p. 247; 299).

Assim, é possível perceber que o Padre/Fidalgo Dom Vicente Nogueira, homem honrado, segundo os inquisidores - ou seja, bem nascido, tal como nos lembrou Padre Raphael Bluteau - recebeu a misericórdia do Santo Ofício por ter dado mostras de arrependimento e por ter colaborado com ele, ainda que alguns cúmplices, um deles preso, 
“tere’ dito doR. antes delle Confessar”. Mas também teve seus privilégios. Certamente, numa sociedade calcada numa complexa hierarquia de status, na qual a situação econômica nem sempre era o elemento preponderante, mas sim a busca pela distinção, fator que "comandava as aspirações de ascensão social" (VAINFAS, 2000, p. 44), seu privilégio de nascimento o ajudou a escapar dos grilhões das galés e, até mesmo, da fogueira da Inquisição. 


\section{Referências}

\section{1) Fontes}

Arquivo Nacional da Torre do Tombo, Inquisição de Lisboa, Processo n. 4241.

Arquivo Nacional da Torre do Tombo, Inquisição de Lisboa, Processo n. 5846.

Arquivo Nacional da Torre do Tombo, Inquisição de Lisboa, Processo n. 10426.

\section{2) Bibliografia}

AGUIAR, Asdrúbal António de. Crimes e delitos sexuais em Portugal na época das ordenações. Lisboa: Instituto de Medicina Legal de Lisboa. Separata dos números 1 e 2 do III vol. (Mar. e Jun. de 1930). Archivo de Medicina Legal.

ASSUNÇÃO, Paulo de, e FRANCO, José Eduardo. As metamorfoses de um polvo. Religião e Política nos Regimentos da Inquisição Portuguesa (Séc. XVI-XIX). Lisboa: Prefácio, 2004.

BECHTEL, Guy. A carne, o diabo e o confessor. Lisboa: Dom Quixote, 1998.

BETHENCOURT, Francisco. História das inquisições: Portugal, Espanha e Itália. Séculos XV - XIX. São Paulo: Companhia das Letras, 2000.

BLUTEAU, Raphael. Vocabulario portuguez e latino. Coimbra, 1712-1728. Disponível em $<$ http://www.ieb.usp.br/online/index.asp>. Acesso em 27 de mar de 2009.

BOSWELL, John. Cristianismo, tolerancia social y homosexualidad. Los gays en Europa occidental desde el comienzo de la Era Cristiana hasta el siglo XIV. Barcelona: Muchnik, 1998.

CALAINHO, Daniela Buono. Agentes da fé. Familiares da Inquisição Portuguesa no Brasil Colonial. Bauru: EDUSC, 2006.

CARDIM, Pedro. Religião e Ordem Social. Em torno dos fundamentos católicos do sistema político do Antigo Regime. Revista de história das ideias. Instituto de História Económica e Social. Faculdade de Letras da Universidade de Coimbra. Coimbra, 2001.

EMBIL, José María Urteaga; SALVADOR, Carlos Corral (dir.). Dicionário de Direito Canônico. São Paulo: Loyola, 1993.

FEITLER, Bruno. Nas malhas da consciência. Igreja e Inquisição no Brasil. São Paulo: Alameda, 2007.

MOTT, Luiz. Homossexuais da Bahia. Dicionário Biográfico (Séculos XVI-XIX). Salvador: Grupo Gay da Bahia, 1999. 
Justitia et Misericordia: a Inquisição Portuguesa e a repressão ao nefando pecado de sodomia. In: NOVINSKY, Anita; CARNEIRO, Maria Luiza Tucci (Orgs.). Inquisição: ensaios sobre mentalidade, heresias e arte. Rio de Janeiro: Expressão e Cultura; São Paulo: EDUSP, 1992.

. Pagode português: a subcultura gay em Portugal nos tempos da Inquisição. Mensagem recebida por <veronicagomes_07@yahoo.com.br>, em 03 de abr. de 2005.

PEREIRA, Isaías da Rosa. A Inquisição em Portugal. Séculos XVI-XVII - Período Filipino. Lisboa: Vega, 1993.

RICHARDS, Jeffrey. Sexo, desvio e danação. As minorias na Idade Média. Rio de Janeiro: Jorge Zahar, 1993.

SANTOS, Georgina Silva dos. Ofício e sangue: A Irmandade de São Jorge e a Inquisição na Lisboa Moderna. Lisboa: Colibri, 2005.

VAINFAS, Ronaldo (Dir.). Dicionário do Brasil colonial (1500-1800). Rio de Janeiro: Objetiva, 2000.

Sodomia, Mulheres e Inquisição: notas sobre sexualidade e homossexualismo feminino no Brasil colonial. Anais do museu paulista. Tomo 35. São Paulo: USP, 19861987.

Trópico dos pecados. Moral, Sexualidade e Inquisição no Brasil. Rio de Janeiro: Nova Fronteira, 1997. 